\title{
Література:
}

1. Гудманян А.Г., Струк І.В. Відтворення фонографічних аномалій діалектного мовлення в перекладі (на матеріалі творів Марка Твена та їх перекладів українською й російською мовами). Одеський лінгвістичний вісник. Одеса. Видавничий дім «Гельветика», 2014. Вип. 4. С. 52-55

2. Кобилянський, Б.В. Діалект і літературна мова. Київ. Рад. шк. 1960. $274 \mathrm{c}$.

3. Комиссаров В. Н. Теория перевода (лингвистические аспекты). М. Высш. шк., 1990. 253 с.

4. Портер Е. Поліанна; пер. 3 англ. Богдана Гора. К. Національний книжковий проект. 2011. 240с.

5. Ребрій О.В. Сучасні концепції творчості у перекладі. Харків. ХНУ імені В. Н. Каразіна, 2012. 376 с.

6. Струк І.В. Стратегії відтворення аномалій діалектного мовлення в перекладі (на матеріалі творів Марка Твена та їхніх перекладів українською та російською мовами). Гуманітарна освіта в технічних вищих навчальних закладах. Київ. Університет «Україна», 2014. Вип. 30. С. 83-97.

7. Eleanor H. P. Pollyanna. 2018. 243 c.

DOI https://doi.org/10.30525/978-9934-26-073-5-2-37

\section{ПРОБЛЕМИ ПЕРЕКЛАДУ ДОКУМЕНТАЛЬНИХ ТРЕВЕЛ-ФІЛЬМІВ}

\author{
Шама I. М. \\ кандидат філологічних наук, \\ доиент кафедри англійської філології \\ Запорізького національного університету \\ м. Запоріжжя, Україна
}

Телевізійна тревел-продукція опинилася в сфері наукового інтересу не так давно і першими увагу на неї (що $є$ закономірним) звернули теоретики та досліджувачі журналістики [8, с. 75]. Для перекладознавців це все ще малодосліджена царина [1, с. 128; 2, с. 252]. Втім, такі фільми постійно перекладаються, будучи вагомою складовою багатьох телевізійних каналів, як от, наприклад, «Discovery», «National Geographic» або «Viasat Explorer». Практика перекладу зразків цього жанру демонструє приклади як високоякісного, адекватного транслятивного 
продукту, так i ті, що рясніють прикрими помилками. Зрозуміло, що тревел-фільми підкоряються власним законам, а, отже, потребують специфіки в доборі перекладацьких стратегій. Для перекладу таких фільмів треба брати до уваги декілька факторів: 1) жанрову специфіку оригіналу; 2) фонову культурну пресупозицію (автора травелога, перекладача, іншокультурного глядача); 3) загальні закономірності та традиції кіноперекладу в культурі, яка сприймає.

Окреслимо основні жанротвірні ознаки тревел-програм / фільмів на телебаченні, виходячи 3 того, що будь-яка телепродукція є первісно креолізованою, оскільки в ній існує щонайменше дві різнокодові складові (текст і «картинка»). Останнє дозволяє долучити до джерел наукової інформації ще й знання про літературний травелог задля опису теле-тревел-тексту як такого.

Для тревел-програм характерним є: 1) особливий сценарій, спрямований на дестинацію; 2) полі-інтенціональний характер оповіді та домінанта інтенції сповіщення / інформування; 3) переважання актуальної інформації та постулат іiі достовірності; 4) зйомки «з натури»; 5) хронотопічна динамічність та використання варіативних засобів локутивності; 6) наявність авторського «я» та вплив авторського бачення на добір фактів; 7) наявність сюжету; 8) наявність діалогу автора та «іншого»; 9) поєднання вербальних та невербальних засобів [2, с. 244; $3 ; 4$, с. $86 ; 6 ; 7 ; 9 ; 11$, с. 183].

Цей далеко не повний перелік ознак жанру телевізійного тревел-продукту безпосередньо впливає на обрання перекладацьких рішень, тим більше, що однією з найважливіших функцій такого роду програм називають функцію посередника в діалозі культур [10, с. 113]. Переклад же і сам по собі відзначено міжкультурним посередництвом, що не може не позначатися на взаємодії тріади «телевізійний тревел-продукт - перекладач - іншокультурний глядач».

Наскільки легко зруйнувати гармонію тріади, згаданої вище, посиливши ентропію, можна зрозуміти 3 найпомітніших помилок в синхронному закадровому перекладі фільмів, які демонструвалися на каналі «Travel» на початку 2000-х. Саме в ці роки в країнах СНД почали освоювати практику теледубляжа. Потік телепродукції іноземними мовами був великим, багато передач транслювалися прямо з супутників. Професійний дубляж був неможливим через обмеженість часу перед поданням в ефір, дорожнечу та масштаби роботи. Тому демонстрація відбувалась без попередньої підготовки 3 синхронним закадровим перекладом, при якому оригінальне мовлення фільму / програми / шоу не прибиралося i його було чути за голосом перекладача або актора 
озвучування [5, с. 23-24]. Як наслідок, фільми з таким войсовером виявилися вельми цікавим та повчальним джерелом прикладів того, якого роду помилки і чому виникають в процесі перекладу і як вони впливають на адекватність сприйняття телепродукту в цілому.

Для аналізу було обрано два фільми. Перший з них - «The Best of Beautiful Britain» (режисери - А. Бріерлі, К. Войс, Г. Коул, продюсер К. Войс) - відноситься до телевізійної тревел-журналістики пізнавальнопросвітницького типу. Це фільм-травелог 3 елементами дорожнього нарису та тревел-репортажу. Другий - один 3 епізодів серії фільмів Ж. Бервутса «Taste of Travel», який теж можна віднести до жанру телевізійної тревел-журналістики, але 3 домінуванням телевізійного тревел-нарису 3 елементами теле-травелога і тревел-репортажу. Ж. Бервутс знімав травелог симбіотичного типу. Це означає, що він намагався опинитися всередині хост-культури. Звідси й особливості власне тревел-тексту: в ньому, немов бриколаж, використовуються алюзії, впізнавані фрази і т. ін.

Виходячи зі сказаного, вихідний медіатекст треба сприймати 3 урахуванням епохи та предметної області, про які йдеться. Інакше величезний шар пам'яті іншої культури пройде повз глядача, а сам переклад не виконає функцію, яка в ньому закладена, - функцію знайомства з іншим культурним досвідом.

Помилок в войсовер фільмів, що аналізуються, досить багато. Більшість зумовлена відсутністю необхідних фонових культурних пресупозицій у закадрового перекладача, але $є$ й такі, котрі виникають від ігнорування відеоряду або ж через відсутність попередньої підготовки до перекладу.

Фільм, документальний в тому числі, - це креолізований, гібридний, мультикодовий текст. Тому перекладач повинен розуміти й передавати смисл всіх планів вираження як вербального, так і невербального рядів. При цьому дуже важливо слідкувати за координацією картинки та тексту, враховуючи основоположні характеристики адекватного войсоверу: ізохронію, кінетичну синхронію i, найголовніше, синхронізацію тексту і візуалізації [12]. Порушення єдності візуального та вербального рядів призводить до дисонансу в глядацькому сприйнятті кіно-тревел-продукту.

До цього ж може призвести і неправильний вибір відповідника в цільовій мові. Зазвичай, такий вибір існує в межах релевантних відповідників. Відокремлення тих 3 них, котрі виявляться пертинентними в контексті відеофрагменту, і становить завдання перекладача. 
У випадку з телевізійними фільмами жанру «тревел» пертинентними перекладацькими відповідниками можна вважати такі, що: 1) корелюють 3 лінгвістичною та культурною специфікою первотвору; 2) не порушують мультикодовості жанру; 3) не викривляють авторського «я» мандрівника; 4) реалізують основні функції жанру «травелог»; 5) не ігнорують дифузію різних жанрів тележурналістики в вихідному тексті; 6) орієнтовані на іншокультурного глядача.

Стратегія пертинентності, отже, повинна стати однією 3 основних стратегій, що використовуються при перекладі документальних тревел-фільмів / програм, а сам жанр потребує перекладознавчої уваги.

\section{Література:}

1. Айрапетова В. Документальный фильм как жанр киноискусства и регистр. URL: http://publications.ysu.am/wp-content/uploads/2019/05/13_V_ HAYRAPETOVA.pdf

2. Горшкова В. Е. Художественный кинодиалог vs документальный: жанровая специфика перевода. Вестник РуДН. Серия Лингвистика. 2016. T. 2. № 3. С. 243-259.

3. Дускаева Л. П. Познавательно-просветительская медиаречь: репрезентация коммуникативного сценария трэвел-медиатекстов. Научные Ведомости Белгородского государственного университета. Серия Гуманитарные науки. 2014. № 26 (197). Вып. 24. С. 85-92.

4. Калинин И. В. Концепции изучения трэвел-медиатекста (литературоведческая, маркетинговая и медиалингвистическая). Культурная жизнь Юга России. Краснодарский государственный институт кульmуры. 2018. № 1 (68). С. 83-87.

5. Матасов Р. А. История кино/ видео перевода. Вестник МГУ. Серия 22. Теория перевода. 2008. № 3. С. 3-27.

6. Медведева А.Р. Трансформация жанра травелога в русле метамодернистской тенденции. Знак: проблемное поле медиаобразования. Челябинск: ООО Центр интеллектуальных услуг «Энциклопедия». 2019. № 3 (33). С. 160-165.

7. Муха А. В., Федосеева Н. И. Содержательная и жанровая специфика трэвел-журналистики в зависимости от видов СМИ. ОгарёвOnline. 2015. №19 (60). URL: https://cyberleninka.ru/article/n/soderzhatelnaya-i-zhanrovaya-spetsifika-trevel-zhurnalistiki-v-zavisimosti-ot-vidov

8. Показаньева И. В. Генезис отечественного научно-популярного телевидения географической тематики: возникновение телевизионной трэвел-журналистики. Bопросы теории и практики журналистики. 2014. № 5. С.74-82. 
9. Показаньева И. В. К теоретизации отношений автора и дестинации в трэвел-журналистике. Universum: Филология $u$ искусствоведение. 2014. № 8 (10). URL: http://7universum.com/ru/ philology/archive/item/1529

10. Полєжаєв Ю. Г. Тревел-журналістика у фокусі наукових досліджень: аналітичний огляд російського досвіду. Держава та регіони. Гуманітарні науки. 2014. № 3. С. 110-114.

11. Редькина Т. Ю. Рекламные интенции в трэвел-медиатексте. Медиатекст как полиинтенциональная система. Сборник статей. СанктПетербург : Санкт-Петербургский государственный университет, 2012. C. 183-190.

12. Matamala A. Translating documentaries: from Neanderthals to the Supernanny // Perspectives. 2009. No. 17 (2). Pp. 93-107. URL: https://www.tandfonline.com/doi/abs/10.1080/09076760902940112? scroll=top\&needAccess $=$ true $\&$ journalCode $=r m p s 20$ 